\title{
立地論についてのコメント
}

\author{
目良浩一
}

\section{1. 立地論の性格}

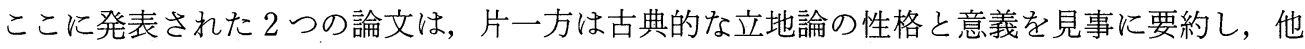
方は最近の発展の著しい経済学分野に和ける立地論の貢献を鮮やかに描き出している。非常に 対照的な論文である。しかし，この対照によって，逆に立地論の全貌が明らかになっている。こ こでは，両論文についての細部についてのコメントをするよりも，ここに描かれた立地論の現 代的意味について考察したい。

立地論の基礎は, 家計や企業なりの意志決定主体のミク口的な意志決定についての分析であ る。この点ではミクロ経済学の一分野であるとも考学ることができる。これは特に空間に拈け る意志決定を考察するものであり，社会における人間活動の空間的分布を考劣る上では最も重 要な基盤になると考えられる。地域学の母であるWalter Isard が先ず最初に立地論の改良を試 みたのは当然であったと言光よう。(:1)

しかしながら，1970 年以後の新都市経済学 (NUE) と称される住宅立地論や金本論文に言及 されている少数の理論的貢献を除いて，近年では立地論はあまり「地域学者」によって注目さ れなくなってきている。特に具体的ケースを扱った問題の検討の際には, 立地論は殆んと顧み られずに，代って，エコノメトリックス，I-O，そして現在ではかなり廃れて来たがシステム・ ダイナミックスなどの手法が用いられることが多い。これらはマクロ現象を取扱らに適した手 法で，それなりの意味はあるが，個々の意志決定主体の行動性向を理解して，そこからマクロ 現象を説明しょうとする完全主義的社会科学者の理想からすると甚だ好ましくない方法であ る。

特にエコノメトリックスや I-Oの手法は基本的には過去に起生したマクロ的変数の関係を 記述する方法であり, ある変数が未経験の領域に移動した場合にその関係が保持されるといら 保障はない。システム・ダイナミックスの場合にはそのような関係が過去に存在したという確 認も必要でないのである。そのような関係をもし立地論を基礎として導くことができるとすれ ば，それはより信頼できるであろう。何故なら，それは効用や利潤最大化などのより基本的な

* 筑波大学

(注 1) Walter Isard,Location and Space-Economy. Wiley and MIT Press, 1956, 
人間の行動原理に基づいているからである。

しかしながら,立地論の現実的政策問題への応用には 2 つ問題点があると考えられている。 第 1 は空間問題の必然的に持っている分析の困難さである。通常の問題に空間的次元が加わる ために問題は極めて複雑になるのは当然である。空間を明示的に含まない一般均衡に扣いても 数值解を導くことは困難であるが，地域間一般均衡の数值解を導くことは更に困難である。 Isard 等による地域間一般均衡などの理論的究明も以後の発展にあまり繫がらなかったし,(注2) Lösch による立地論の総合も単に質的な問題の理解に止まざるを得なかった。

第 2 の問題は運送費の重要性の問題である。立地論においては一般に輸送費だけが空間的規 則性を持っているとされていて，従がってそれが立地の主要な決定要因となるのであるが，近 年の輸送関係の技術の発達や生産性の向上は輸送費の相対的な重要性を軽減させて来ている。 立地論は主に西岡氏の言ら運送指向の活動に適合するものであり, 非運送指向の活動には非力 である。この事実が立地論があまり脚光を浴びない一つの要因となっている。換言すれば，空 間的次元を持たない分析をもってしても，その分析誤差は相対的に小さくなって来ているとも 言えるかもしれないのである。

\section{2. 立地論への期待}

では立地論はもはや不必要であるのだろらか。又は，今後の立地論に何を期待すればよいの だろらか。

金本氏はこの点に関して，立地論は経済学に和ける非凸性の理解を深める役割を強調してい る。評者もこの点に同感である。しかし，この点は更に強調する必要がある。従来の凸性の仮 定のもとに行なわれて来た経済理論は, その仮定に保護された分析の容易さによって各種の結 論を導くことができたが, 現点の経済には非凸性は程度の差こそあれ各所に見出されるので, 従 来の理論からの結論は現実への適合性といら観点からは再検討されなければならない。非凸性 の問題は単に立地論にとって重要であるのみならず,より一般に経済分析に重要な問題であり, それが最も明瞭に感知されるのが立地論であるとい方よう。その意味では立地論は経済学のフ ロンティアである。

立地論に解答の提供を期待している政策問題は数多い。地価問題, 固定資産税, 住民税等の 役割や税率, 土地利用規制問題など各種の都市問題に対して有用な経済学的観点からの政策提 言が引き出し得るものと思う。金本氏が述べているように，この 10 年間にかなりのことが明ら

(注 2) Walter Isard "General Interregional Equilibrium," Papers and Proceedings of the Regional Science Association, 3 (1957), pp. 35-60 及び Walter Isard and David J. Ostroff "General Interregional Equilibrium” Journal of Regional Science 2 (Spring, 1960), pp. 67-74 参照。 
かになってきている。規模の経済性や公共財の地代創出効果や都市成長過程におけるスプロー ルの積極的効果などはその代表的なものである。今後の 10 年でも更に数多くの有用な関係が明 らかになるであろう。

このような分野に拈いては，物資の輸送から離れて人々の輸送に着眼することによって立地 論の存在理由を発見したのであり, 着眼点を変えることによって立地論の有用性は人間の活動 と共に続くであろら。

次に立地論が有用性を増大するために必要だと思われる事項をいくつか挙げておこう。第 1 は個人又は家計の立地選好に関するより正しい理解である。賃金格差，通勤費や土地面積など の伝統的な変数の他にも主要な変数があると思われる。この点の改善がなければ最近の欧米の 都市化の逆転現象（Urbanijation Reversal）は理解できないであろう。

第 2 は立地決定における情報の役割である。輸送と通信はある程度代替的な活動であるが, 情 報の役割には通常の需要把握, 代替技術の理解などの他に技術進歩の効果もある。情報伝達技 術が急速に変化している今日に抢いては，立地に拈ける情報の役割はもっと真剣に採りあげら れるべきであろう。

第 3 には立地決定の確率論的アプローチがより注目を受けるべきであろう。グラビティ・モ デルを確率論的に解釈する動きも出て来ているが, (淮3) 確率論的アプローチをすることによっ て立地論の説明力は大巾に改善するだろう。

上記のような点に执いて改善がなされるならば, 立地論はより親しみのある, 有用な社会科 学の理論として重要な役割を果し続けるであろう。

（注 3）この点に関しては下記の論評に詳しい。Chang-i Hua and Frank Porell “A Critical Review of the Development of the Gravity Model" International Regional Science Review 4 (Winter, 1979), pp. 97-126. 